\title{
Pemahaman Peserta Didik terhadap Perundungan di SMP Negeri 11 Yogyakarta
}

\author{
Aulia Ariska, ${ }^{a, 1}$ Trisna Sukmayadi ${ }^{b, 2^{*}}$ \\ 1,2 Program Studi PPKn, Universitas Ahmad Dahlan, Yogyakarta \\ a aulia1400009008@webmail.uad.ac.id, ${ }^{\mathrm{b}}$ trisnasukmayadi@ppkn.uad.ac.id \\ * korespondensi penulis
}

\begin{abstract}
ABSTRAK
Pemahaman tentang perundungan (bullying) sangat penting bagi para peserta didik, supaya mereka tidak lagi menjadi korban perundungan pihak tertentu. Tujuan penelitian ini adalah untuk melihat tingkat pemahaman peserta didik terhadap perundungan. Penelitian ini menggunakan pendekatan kualitatif dengan jenis penelitian deskriptif. Subjek penelitian adalah peserta didik kelas VIII dan IX SMP Negeri 11 Yogyakarta, dan objek penelitian adalah pemahaman peserta didik tentang perundungan. Metode pengumpulan data dilakukan dengan cara wawancara mendalam, observasi terhadap lingkungan sekolah dan studi dokumentasi. Teknik analisis data menggunakan reduksi data, klasifikasi data, penyajian data, dan penarikan kesimpulan. Hasil penelitian menunjukkan bahwa: 1) peserta didik mengetahui dan mampu menerjemahkan arti perundungan; 2) peserta didik mampu mengetahui faktor penyebab dan bentuk-bentuk perundungan; dan 3) peserta didik mampu memahami dampak perundungan dan mampu memberikan solusi permasalahan.
\end{abstract}

Kata kunci: pemahaman, perundungan, peserta didik, PPKn

\begin{abstract}
An understanding of bullying is very important for students, so that they are no longer victims of bullying from certain parties. The purpose of this study was to see the level of understanding of students towards bullying. This research uses a qualitative approach with descriptive research type. The research subjects were students of class VIII and IX of SMP Negeri 11 Yogyakarta, and the object of the research was the students' understanding of bullying. The method of data collection was carried out by means of in-depth interviews, observation of the school environment and documentation study. Data analysis techniques used data reduction, data classification, data presentation, and drawing conclusions. The results showed that: 1) students knew and were able to interpret the meaning of bullying; 2) students are able to know the causes and forms of bullying; and 3) students are able to understand the impact of bullying and be able to provide solutions to problems.
\end{abstract}

Keywords: understanding, bullying, students, PPKn

Copyright (C2019 Universitas Ahmad Dahlan, All Right Reserved

\section{PENDAHULUAN}

Perkembangan zaman yang terjadi dalam dunia pendidikan secara signifikan telah mengubah pola pikir peserta didik maupun pendidik, dari pola pikir tradional ke arah pola pikir yang modern. Perubahan pola pikir itu mengarah pada usaha pencapaian peran dan fungsi pendidikan sebagai usaha dan terencana untuk mewujudkan suasana belajar yang baik dan proses pembelajaran untuk peserta didik secara aktif dengan mengembangkan potensi yang terdapat dalam peserta didik seperti spiritual keagamaan, kepribadian, kecerdasan, akhlak mulia, serta keterampilan yang diperlukan untuk dirinya dan masyarakat.

Tidak semua perilaku manusia berasal dari bawaan manusia. Ada sebagian perilaku yang merupakan hasil dari proses belajar yang menciptakan suatu hasil pencapaian dari proses pembelajaran. Salah satu faktor yang mempengaruhi perilaku adalah lingkungan sekolah.
Maka dari itu sekolah mempunyai peran penting dan tanggung jawab yang besar dalam membentuk perilaku belajar peserta didik yang baik. Dilihat dari pengertiannya pendidikan merupakan suatu asset penting bagi terbentuknya suatu karakter peserta didik yang menjadi salah satu tujuan pendidikan.

Pendidikan tidak hanya memberi pengetahuan semata, tetapi juga memperhatikan perkembangan sikap dan kepribadian peserta didik secara terintegrasi melalui pendidikan. Namun, seiring perkembangan zaman, tujuan pendidikan semakin berkurang misalnya saja sekolah yang idealnya menjadi tempat menyenangkan berubah menjadi tempat mengerikan, bahkan mengancam jiwa. Sekolah yang seharusnya menjadi tempat untuk mencari kawan berubah menjadi tempat mencari lawan.

Mata pelajaran Pendidikan Pancasila dan Kewarganegaraan (PPKn) sebagai salah satu unsur pendidikan memegang peranan penting 
terhadap kasus perundungan, yaitu proses mendisiplinkan anak secara positif dalam berinteraksi dengan cara menghormati, berempati, bertoleransi, menghormati perbedaan, serta penguatan moral dan karakter peserta didik. Pendidikan karakter merupakan pendidikan nilai, pendidikan budi pekerti, pendidikan moral, pendidikan watak yang bertujuan mengembangkan kemampuan seluruh warga sekolah untuk memberikan keputusan baik-buruk, keteladanan, memelihara apa yang baik dan mewujudkan kebaikan itu dalam kehidupan sehari-hari dengan sepenuh hati. Namun, saat ini banyak terjadi kasus perundungan, seperti kekerasan seksual, kekerasan fisik di kalangan pelajar yang menyebabkan penurunan moral peserta didik.

Kurangnya perhatian terhadap peserta didik dilatarbelakangi minimnya pendidikan moral saat ini. Oleh karena itu melalui pembelajaran PPKn diharapkan dapat meningkatkan sikap moral peserta didik. Sikap moral yang diharapkan dapat berupa sikap saling menghargai antar sesama manusia dan sikap saling menghormati sebagai wujud manusia yang bermoral dan beretika. Menanamkan sikap moral melalui pembelajaran PPKn sangat peting dilakukan pada kalangan peserta didik agar tumbuh generasi muda yang memiliki sikap moral yang baik.

Perundungan adalah situasi dimana terjadi penyalahgunaan kekuatan atau kekuasaan yang dilakukan oleh seseorang atau sekelompok orang kepada pihak-pihak lainnya. Pihak yang kuat di sini tidak hanya kuat dari segi fisik, tetapi bisa juga kuat secara mental. Dalam hal ini sang korban perundungan tidak mampu membela atau mempertahankan dirinya karena lemah secara fisik maupun mental. Perundungan bukan sekadar tindakan yang dilakukan, tetapi dampak tindakan tersebut bagi korban, misalnya seorang peserta didik mendorong bahu temannya secara kasar. Bila yang didorong merasa terintimidasi, apalagi bila tindakan tersebut dilakukan secara berulangulang, maka perilaku perundungan telah terjadi. Selanjutnya bila peserta didik yang didorong merasa tidak terintimidasi maka tindakan tersebut belum dikatakan perundungan.

Pelaku perundungan pada umumnya adalah kakak kelas pada suatu tingkat. Mereka biasanya memiliki kekuatan atau kekuasaan lebih untuk menekan atau melumpuhkan korban. Perundungan terjadi bila pelaku memilki kekuasaan yang lebih tinggi sehingga mereka dapat melakukan kekerasan terhadap orang lain yang dianggap lebih rendah. Pelaku perundungan dapat juga dilakukan oleh teman sekelas, baik yang dilakukan perseorangan maupun oleh kelompok. Perbuatan perundungan yang sering terjadi dan dianggap sudah menjadi tradisi dari tahun ke tahun adalah perilaku perundungan ketika Masa Orientasi Siswa (MOS).

Hasil pengamatan awal di SMP Negeri 4 Manggar Belitung ditemukan beberapa kasus perundungan terhadap peserta didik. Bentuk perundungan yang terjadi antara lain kekerasan fisik yang dilakukan guru, yaitu memukul peserta didik dengan menggunakan benda tajam. Di tempat lain, hasil survei Tim Yayasan Semai Sejiwa Amini (2008) bahkan menemukan bahwa kasus perundungan ditemukan pada beberapa sekolah di Yogyakarta, mulai dari jenjang SD sampai SMA. Salah satu isu penting yang menjadi sorotan tim survei dalam kegiatan ini adalah tindakan perundungan yang terjadi di lingkungan sekolah. Kekerasan yang terjadi di lingkungan sekolah bukan lagi hal yang biasa bagi peserta didik. Kekerasan layaknya sudah menjadi makanan sehari-hari. Cara mendidik anak yang cenderung menggunakan kekerasan di rumah dan di sekolah tanpa disadari telah mengajarkan anak untuk melakukan hal serupa kepada temantemannya.

Berbagai macam hasil penelitian menyatakan bahwa individu yang menjadi korban perundungan teridentifikasi memiliki karakteristik seperti depresi, pasif, rasa malu yang berlebihan, trauma dan menarik diri dari lingkungan sosialnya. Sementara itu, bagi pelaku perundungan, ia memiliki kecenderungan untuk terlibat dalam perilaku kriminal saat dewasa nanti dan cenderung tidak memiliki sikap empati. Kasuskasus perundungan seperti halnya gunung es, yang muncul di permukaan hanya beberapa kasus, tetapi sebenarnya lebih banyak kasus yang tidak terungkap.

Penelitian-penelitian tersebut di atas juga menunjukkan bahwa peserta didik yang menjadi korban perundungan akan mengalami kesulitan dalam bergaul. Berbagai perilaku menyimpang yang dilakukan peserta didik disebabkan kurangnya pemahaman tentang perundungan, dan nilai yang diterimanya. Dalam bertindak bukan berarti anak tidak tahu apa yang dilakukannya adalah perbuatan yang salah, tetapi pemahaman baik dan buruk anak masih mengacu pada suatu rumusan bahwa tingkah laku benar bila tidak dihukum dan salah bila dihukum.

\section{METODE PENELITIAN}

Jenis penelitian ini adalah penelitian deskriptif kualitatif. Lokasi penelitian di SMP Negeri 11 Yogyakarta di jalan HOS Cokroaminoto 127 Yogyakarta. Subjek penelitian adalah peserta didik kelas VIII dan IX, dan objek penelitian 
adalah pemahaman peserta didik tentang perundungan. Metode pengumpulan data yang dilakukan adalah wawancara semi struktur, yaitu wawancara yang masuk dalam kategori indept atau wawancara mendalam. Teknik analisis data dilakukan melalui tahapan reduksi data, klasifikasi data penyajian data, dan penarikan kesimpulan.

\section{HASIL DAN PEMBAHASAN}

SMP Negeri 11 berlokasi di Jalan HOS Cokroaminoto 127 Yogyakarta, berdiri secara resmi pada tahun 1979. Sekolah ini terletak di tempat yang strategis, dekat dengan jalan raya sehingga memudahkan akses menuju lokasi sekolah tersebut. Sekalipun berada dekat dengan jalan raya, tetapi tidak mempengaruhi suasana proses pembelajaran di sekolah, kondisi pembelajaran tetap nyaman dan kondusif.

Hasil penelitian menggambarkan tiga konsep pemahaman terhadap perundungan, yaitu kemampuan untuk menerjemahkan, pemaknaan, dan ekstrapolasi perundungan. Kemampuan menerjemahkan perundungan. Berdasarkan hasil penelitian, dapat dinyatakan bahwa peserta didik SMP Negeri 11 Yogyakarta mampu menafsirkan perundungan. Kemampuan menafsirkan perundungan tergambar saat diajukan pertanyaan tentang definisi atau pengertian dari perundungan, semua responden mengetahui pengertian perundungan. Responden mengatakan bahwa perundungan yaitu tindakan kekerasan yang dilakukan secara berulang-ulang.

Kemampuan pemaknaan faktor-faktor penyebab terjadinya perundungan. Berdasarkan data konsep pemahaman pemaknaan yang diperoleh dari hasil penelitian dapat dinyatakan bahwa peserta didik mampu memahami faktorfaktor penyebab terjadinya perundungan, yaitu faktor iseng, faktor kepuasan diri, faktor kekuasaan atau kekuatan seseorang untuk melakukan perundungan, dan faktor balas dendam. Pemahaman tentang faktor-faktor penyebab terjadinya perundungan penting dimiliki peserta didik agar tidak ada yang merasa dirinya pantas untuk menindas, sebab perasaan pantas menindas ini akan menumbuhkan sikap merendahkan orang lain. Januarko (2014) menyatakan bahwa ketika seorang penindas merasa kebutuhan untuk menjatuhkan seseorang agar dirinya merasa hebat, maka dia tidak perlu susah payah menemukan dalih guna menindas seseorang. Oleh karenanya Coloroso (2003) mengemukakan bahwa dalam perundungan terdapat tindakan permusuhan yang dilakukan secara disengaja dan sadar terhadap korban yang bertujuan untuk menyakiti seseorang, seperti menakuti dengan memberi ancaman dan teror terhadap korban.
Kemampuan memberikan contoh perundungan. Berdasarkan hasil penelitian, diketahui bahwa peserta didik mampu menunjukkan atau menyebutkan contoh-contoh perundungan, yaitu perundungan yang ada di lingkungan sekolah, seperti peserta didik mengejek teman sekelasnya dengan sebutan yang dapat menyinggung perasaan korban, dan memukul korban sehingga korban merasakan kesakitan. Contoh yang dikemukakan peserta didik menunjukkan bahwa kasus perundungan telah menjadi isu yang diketahui umum.

Data perundungan yang dimuat pada kanal berita online menunjukkan bahwa kasus perundungan juga terjadi pada siswi SMP Negeri 3 Pangkal Pinang yang dipaksa untuk mencium kaki teman sekolahnya, ditendang, dan dipukul (Meika, 2018). Kasus perundungan itu terjadi karena adanya kesalahpahaman terhadap teman sekelasnya. Kasus tersebut menunjukkan bahwa perundungan di sekolah masih sering terjadi terhadap teman sekelasnya. Kasus perundungan pun masih sering terjadi pada saat MOS. Mempertontonkan kekuasan yang dimiliki sangat sering dilakukan oleh senior terhadap korban yang menurutnya lemah dan tidak mempunyai kekuatan. Astuti (2008) mengungkapkan bahwa lingkungan sekolah yang kurang baik pun menjadi penyebab terjadinya suatu perundungan, misalnya saja siswa yang bergaul dengan sekelompok peserta didik yang sering melakukan kekerasan akan mengikuti hal tersebut. Demikian pula sikap senioritas yang tidak pernah diselesaikan dapat menjadi salah satu faktor penyebab terjadinya perundungan. Contoh kurang baik yang ditunjukkan guru, ketidakharmonisan di rumah, dan karakter bawaan anak juga turut mempengaruhi terjadinya perundungan.

Kemampuan memahami bentuk-bentuk perundungan. Berdasarkan hasil penelitian, peserta didik mampu memahami bentuk-bentuk perundungan, yaitu a) perundungan fisik seperti memukul, menendang; b) perundungan verbal seperti menghina, memaki; dan c) perundungan mental seperti mengucilkan dan meneror. Priyatna (2010) mengatakan bahwa bentuk-bentuk perundungan ialah bentuk perundungan verbal seperti mengolok-olok nama panggilan, melecehkan penampilan seseorang dengan menjuluki seseorang, menakuti-nakuti, bentuk perundungan mental atau sosial seperti mempermalukan korban didepan umum sehingga korban merasa malu, dikucilkan dari pergaulan. Tidak hanya perundungan verbal dan mental, tetapi juga bisa berupa perundungan fisik seperti menendang, dan memukul korban. 
Bentuk-bentuk perundungan menurut banyak ditemui di lingkungan sekolah. Banyaknya perundungan yang terjadi terhadap peserta didik seperti dikatakan responden merupakan bentuk yang dapat menyebabkan peserta didik tidak percaya diri. Hal ini juga sesuai dengan pandangan Parson (2009) yang mengelompokkan jenis-jenis perilaku perundungan dalam tiga kelompok, yaitu jenis perundungan verbal atau tertulis yang meliputi perilaku mengatai, ledekan seperti menyebut korban dengan sebutan cungkring, menakut-nakuti lewat email, dan SMS yang menyakitkan. Jenis perundungan fisik yang meliputi perilaku yang termasuk, yaitu memukul, menendang, menginjak, menyerang, mengancam dengan kekerasan dan paksaan. Terakhir, jenis perundungan sosial, meliputi perilaku yang termasuk merangkai rumor dan gosip, mengucilkan, mempermalukan, atau mencemooh.

Pemahaman peserta didik tentang bentuk perundungan yang paling sering disebutkan adalah bentuk perundungan fisik dan bentuk perundungan verbal. Kedua bentuk perundungan itu memiliki pengaruh besar terhadap peserta didik. Dalam kedua bentuk perundungan tersebut peserta didik akan mengalami dampak yang cukup serius bahkan dalam waktu yang cukup panjang.

Kemampuan untuk memahami dampak perundungan. Perundungan yang terjadi bisa mengakibatkan dampak yang berujung dengan mental peserta didik. Karena itu, perilaku perundungan harus dicegah agar tidak terjadi dampak-dampak yang cukup serius ke depannya. Hasil penelitian menunjukkan bahwa peserta didik di SMP Negeri 11 Yogyakarta mempunyai kemampuan memahami dampak perundungan yang terjadi, yakni peserta didik atau korban akan merasa takut untuk masuk sekolah sehingga korban sering bolos, peserta didik akan merasakan sedih dan merasa bahwa dirinya tidak mempunyai teman, terganggunya mental korban atau peserta didik, berdampak bunuh diri terhadap korban, dan depresi.

Kemampuan memahami solusi untuk mencegah perundungan. Hasil penelitian menunjukkan bahwa solusi untuk mencegah terjadinya perundungan ialah dengan tidak memilih-milih teman dalam bergaul dan berperilaku yang baik terhadap teman agar tidak menjadi korban perundungan. Dengan tidak memilih-milih teman dalam bergaul, maka pelaku tidak akan melakukan tindakan perundungan karena tidak akan membeda-bedakan sesama teman. Respons peserta didik sejalan dengan pendapat Wiyani (2014) yang menyebutkan bahwa diperlukan peran dari semua pihak yang terkait dengan lingkungan hidup remaja untuk mencegah perilaku perundungan.
Guru di sekolah misalnya memiliki peran penting dalam mencegah perilaku perundungan.

Guru mata pelajaran PPKn pun dapat terlibat secara aktif dalam mencegah terjadinya perundungan. Jika ada kasus dimana peserta didik yang menjadi pelaku perundungan memanggil korban dengan sebutan kurus sehingga korban merasa tidak percaya diri, maka guru mata pelajaran PPKn dapat mencegah terjadinya perundungan dengan memberikan bimbingan kepada peserta didik bekerja sama dengan guru Bimbingan Konseling maupun guru mata pelajaran lainnya, staff dan kepala sekolah. Pihak guru dapat menyediakan waktu terbaik untuk berkomunikasi dengan peserta didik dan mengajak peserta didik untuk berempati, dan mengajarkan peserta didik untuk berperilaku baik terhadap sesama teman. Cara berkomunikasi yang baik akan membuat peserta didik lebih terbuka terhadap siapa pun, peserta didik akan merasa bahwa sekolah menjadi tempat yang aman.

Kemampuan memahami solusi untuk menanggulangi perundungan. Berdasarkan hasil penelitian, terungkap bahwa peserta didik dapat mampu memahami dan memberikan solusi untuk menanggulangi perundungan, yaitu dengan mengoptimalkan peran guru Bimbingan Konseling dalam memberikan penyuluhan terhadap peserta didik tentang perundungan dan seluruh keluarga besar sekolah agar mendukung dalam pencegahan perilaku perundungan.

\section{KESIMPULAN}

Hasil penelitian ini secara keseluruhan diketahui bahwa peserta didik di SMP Negeri 11 Yogyakarta mempunyai pemahaman yang cukup baik tentang perundungan. Hal ini ditunjukkan dari kemampuan peserta didik yang baik dalam menerjemahkan, memberi makna, dan ekstrapolasi tentang pemahaman perundungan.

\section{DAFTAR PUSTAKA}

Astuti, P. R. (2008). Meredam Bullying: 3 Cara Efektif Menanggulangi Kekerasan pada Anak. Grasindo.

Coloroso. (2003). Perilaku Agresif, Buku Panduan Psikologi Sosial. Erlangga.

Januarko, W. (2014). Studi tentang penanganan korban bullying pada siswa SMP seKecamatan Trawas. BK UNESA, 4(2).

Meika, I. (2018). Siswi SMP di Pangkal Pinang Jadi Korban Bullying di Paksa Sujud Cium Kaki Teman. tribunnews,com.

Parson. (2009). Bullied Teacher Bullied. Grasindo. 
Priyatna, A. (2010). Lets end bullying: memahami, mencegah dan mengatasi bullying. PT. Alex Media Komputindo.

Wiyani, N. A. (2014). Save our children from school bullying. Ar-Ruz Media.
Yayasan Semai Jiwa Amini. (2008). Mengatasi kekerasan di sekolah dan lingkungan sekitar anak. Gramedia. 